\title{
Erratum to: A novel approach for the development of tiered use biological criteria for rivers and streams in an ecologically diverse landscape
}

\author{
R. William Bouchard Jr. • Scott Niemela • John A. Genet • Chris O. Yoder • \\ John Sandberg • Joel W. Chirhart • Mike Feist • Benjamin Lundeen • Dan Helwig
}

Published online: 31 March 2016

(C) Springer International Publishing Switzerland 2016

Erratum to: Environ Monit Assess (March 2016)

188, Issue 3:196

DOI 10.1007/s10661-016-5181-y

The original version of this article unfortunately contained an error in the Electronic Supplementary Material.

The Electronic Supplementary Material should not be included in the published online paper. However, it has been addressed and is not anymore present in the published copies of the article.

The online version of the original article can be found at doi:10. 1007/s10661-016-5181-y.

R. W. Bouchard Jr., $(\bowtie) \cdot$ S. Niemela $\cdot$ J. A. Genet $\cdot$

J. Sandberg · J. W. Chirhart $\cdot$ M. Feist $\cdot$ B. Lundeen •

D. Helwig

Environmental Analysis and Outcomes Division, Minnesota

Pollution Control Agency, 520 Lafayette Road North, Saint Paul, MN 55155-4194, USA

e-mail: Will.Bouchard@state.mn.us

C. O. Yoder

Midwest Biodiversity Institute \& Center for Applied

Bioassessment \& Biocriteria, P.O. Box 21561, Columbus, OH

43221-0561, USA 